ABDIMAS: Jurnal Pengabdian Masyarakat Universitas Merdeka Malang
Vol.6(1) February 2021, 133-141
i-ISSN: 2721-138X e-ISSN: 2548-7159
ittp://jurnal.unmer.ac.id/index.php/jpkm

\title{
Monitoring Akuaponik dengan Android untuk Meningkatkan Minat Masyarakat dalam Bercocok Tanam di Kecamatan Porong
}

\author{
Wahyu Dirgantara, Rahman Arifuddin, Irfan Mujahidin \\ Departemen Teknik Elektro, Fakultas Teknik, Universitas Merdeka Malang \\ Jl. Terusan Raya Dieng No.62-64 Malang, 65146, Indonesia
}

\begin{abstract}
ARTICLE INFO
Received: 2020-12-04

Revised: 2020-01-14

Accepted: 2021-02-02

ABSTRACT

Sidoarjo Regency, especially Porong District, is an area affected by the Lapindo disaster. The disaster resulted in the closure of several industries and many workers who lost their jobs, agricultural land designation, migration of population from Siring Village to Lajuk. The solution offered to overcome this disaster is by farming using aquaponics techniques. Aquaponics is a farming technique that combines plants and fish. This technique is generally used in urban areas or narrow land. To increase people's interest in farming is by utilizing technology that is used daily. By making a monitoring tool on aquaponics and using an Android phone as a monitoring display to monitor the flow of pool water in aquaponics. This monitoring is needed because the water pump that is used to drain the water flow will become clogged with leaves from the plants above it. The results of monitoring proved to be useful and made it easier for aquaponics owners to monitor whether the pool water flow was blocked or the water flow stopped.
\end{abstract}

Keywords:

Aquaponics, Lapindo disaster, Monitoring
(C) 2021 Published by University of Merdeka Malang This is an open access article distributed under the CC BY-SA 4.0 license (https://creativecommons.org/licenses/by-sa/4.0/)

How to cite: Dirgantara, W. D., Arifuddin, R., \& Mujahidin, I. (2021). Monitoring Akuaponik dengan Android untuk Meningkatkan Minat Masyarakat dalam Bercocok Tanam di Kecamatan Porong. Abdimas: Jurnal Pengabdian Masyarakat Universitas Merdeka Malang, 6(1), 133-141. https://doi.org/10.26905/abdimas.v6i1.5077

\section{PENDAHULUAN}

Teknik bercocok tanam yang menggabungkan antara tanaman dan ikan merupakan cara bercocok tanam akuaponik. Teknik ini cocok untuk daerah perkotaan yang tidak memiliki lahan hijau untuk bercocok tanam, daerah industri serta derah yang kurang sumber air (Rahayu et al., 2018). Selain memiliki kelebihan tidak memerlukan lahan yang luas salah satu kelebihan lainnya adalah tidak perlu menguras kolam ikan terlalu sering, hal ini dikarenakan air selalu mengalir dan kotoran ikan yang terserap water pump akan disaring oleh akar tanaman sehingga air tidak mudah keruh serta berbau. Dalam bercocok 
ABDIMAS: Jurnal Pengabdian Masyarakat Universitas Merdeka Malang Volume 6, No. 1, February 2021: 133-141

tanam dapat memanfaatkan teknologi berbasis android dengan memanfaatkan IoT sebagai sistem monitoring jarak jauh.

Android merupakan Operating System (OS) yang dikembangkan linux untuk smart phone atau dikenal dengan komputer tablet. Contoh penggunanaan OS adalah untuk monitoring dan pemberian saran untuk bayi dan yang kekurangan gizi dan pengambilan keputusan untuk cairan penetral ph tanah (Dirgantara \& Arifuddin, 2020; Prasetya et al., 2019). Handphone pada era industri 4.0 merupakan alat yang tidak bisa dipisahkan dalam keseharian (kebutuhan primer), sebagai media informasi dan komunikasi yang bisa secara instan diakses kapanpun serta dimanapun membuat handphone tidak bisa lepas dan selalu berada dibawa kemana-mana. Untuk mengoptimalkan fungsi handphone, sudah banyak dilakukan penelitian seperti handphone untuk pengganti remote control (Syofian, 2016).

Internet of Things (IoT) diterjemahkan sebagai kumpulan benda (things), bisa berupa perangkat fisik (embedded system/hardware), dan bisa saling bertukar informasi, layanan operator atau perangkat lainnya yang terhubung kedalam sistem, sehingga bisa memberikan manfaat secara optimal. Contoh penggunaan IoT dalam penelitian adalah Implementasi IoT Cerdas Berbasis Inference Fuzzy Tsukamoto pada Pemantauan Kadar pH dan Ketinggian Air dalam Akuaponik (Kuswinta \& Arimbawa, 2019).

Kabupaten Sidoarjo dikenal sebagai kota penyangga untuk Kota Surabaya. Sidoarjo merupakan kota yang tumbuh serta berkembang karena industri, pertokoan dan fasilitas layanan nasional dan internasional. Pada 29 Mei 2006 di Desa Siring Kenongo Kecamatan Porong Kabupaten Sidoarjo terjadi bencana nasional berupa semburan lumpur Lapindo (Hidayat, 2007). Dampak bencana tersebut mengakibatkan masyarakat Dusun Pojok kehilangan pekerjaan sebagai buruh pabrik, semakin bertambahnya penduduk Dusun Pojok menyebabkan lahan pertanian beralih fungsi menjadi perumahan warga terdampak bencana semburan lumpur Lapindo.

Mitra kegiatan Pengabdian Kepada Masyarakat (PKM) adalah wanita atau kelompok ibu rumah tangga yang anaknya bersekolah di KB/TK Baitul Ilmi dan Karang Taruna Dusun Pojok RT.03 RW.01 Desa Lajuk. Dengan memilih kelompok mitra ini maka penyebaran informasi kepada masyarakat Dusun Pojok tentang pemanfaatan akuaponik dengan menggunakan monitoring semakin cepat tersebar, serta membantu perekonomian kelompok mitra dari hasil akuaponik yang berupa ikan segar dan sayuran organik.

Akibat berkurangnya lapangan pekerjaan dan beralih fungsinya lahan pertanian memerlukan solusi pemecahan masalah. Solusi yang ditawarkan kepada kelompok mitra adalah membuat percontohan akuaponik dengan menggunakan monitoring aliran air dan suhu. Kerangka solusi akan disajikan dalam bentuk blok diagram pada Gambar 1.

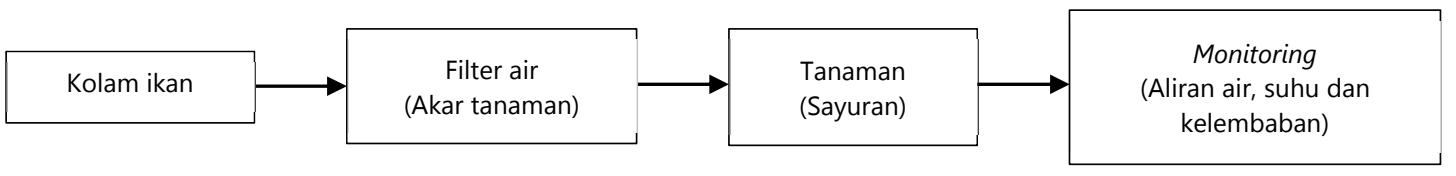

Gambar 1. Blok diagram akuaponik

Proses filter air kolam pada akuaponik menggunakan akar tanaman, kotoran ikan dan bakteri yang ada pada kolam ikan akan dimanfaatkan sebagai makanan serta nutrisi tanaman. Monitoring pada 
akuaponik bertujuan untuk mengetahui terjadinya penyumbatan pada saluran air, mengetahui suhu dan kelembapan di sekitar area kolam. Dalam beberapa kasus yang ditemui, pipa aliran air biasanya tersumbat oleh daun dan lumut yang sudah terlalu menumpuk, sehingga aliran air tidak lancar, membuat tanaman akan layu dan mati. Dengan mengetahui aliran air maka pemilik akuaponik bisa melakukan tindakan jika terjadi permasalahan tersebut. Sebagai gambaran untuk sistem akuaponik diperlihatkan pada Gambar 2.

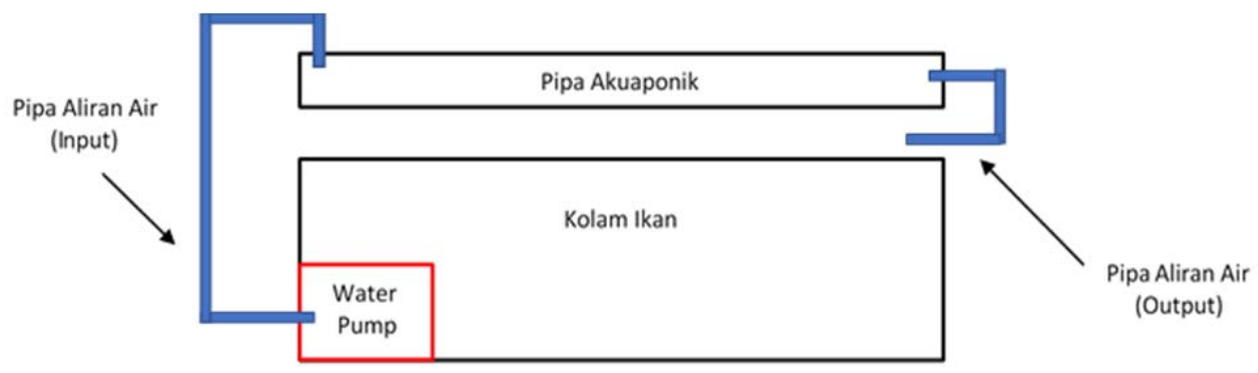

Gambar 2. Pemodelan akuaponik tanpa monitoring

Kegiatan Pengabdian Kepada Masyarakat (PKM) ini bertujuan untuk meningkatkan minat masyarakat terhadap bercocok tanam yang cerdas dan modern. Teknik yang digunakan untuk bercocok tanam dalam PKM ini menggunakan akuaponik dengan menambahkan alat untuk memonitoring suhu, kelembaban dan aliran air. Selain mendapatkan hasil berupa tanaman sayur dan ikan, mengurangi polusi udara dan mengurangi jentik nyamuk juga bisa untuk konsumsi pribadi, dan jika dijual maka hasil dari penjualan bisa digunakan sebagai masukan tambahan untuk kebutuhan rumah tangga.

\section{METODE}

Pelaksanan PKM dalam proses pelaksanaan kegiatan PKM dilakukan dengan dua metode yang digunakan (1) Percontohan dan (2) sosialisasi kepada masyarakat.

\section{Percontohan}

Dalam pelaksanaan PKM di desa mitra perlu dibuat sebuah percontohan dengan maksud dan tujuan supaya dalam pelaksanaan sosialisasi mudah dipahami oleh mitra. Percontohan ini dibuat dalam bentuk portable, hal ini dilakukan supaya akuaponik dan alat bisa ditempatkan di tempat-tempat yang sempit.

Tanaman yang dipakai adalah batang sayuran yang sudah tidak dipakai lagi (dibuang) dan ikan pada kolam akuaponik adalah jenis ikan lele, pemilihan jenis ikan ini adalah selain mampu hidup di kondisi yang kotor juga bisa dijadikan contoh kepada mitra bahwa dengan menggunakan akuaponik cukup mudah diimplementasikan masing-masing individu di lahan yang terbatas. 
ABDIMAS: Jurnal Pengabdian Masyarakat Universitas Merdeka Malang

Volume 6, No. 1, February 2021: 133-141

\section{Sosialisasi}

Sosialisasi merupakan proses yang dilakukan setelah alat dibuat sebagai landasan pengetahuan dan pemahaman sebelum proses implementasi dilaksanakan (Herdiana, 2018). Tujuan sosialisasi adalah membangkitkan potensi lahan tidur milik mitra, meningkatkan minat mitra akan berocok tanam dengan menggunakan teknologi yang sederhana (Wibowo et al., 2020). Dalam pelaksanaannya ada beberapa tahap supaya sosialisasi bisa menghasilkan dampak yang optimal.

\section{Pembagian brosur akuaponik}

Brosur berisikan informasi berupa nama kegiatan, gambar dan penjelasan terkait sistem akuaponik baik yang manual maupun alat monitoringnya. Penjelasan yang ada pada brosur juga bisa dipakai sebagai modul untuk membuat sistem akuaponik.

\section{Tanya jawab}

Tanya jawab merupakan metode yang digunakan untuk mengetahui kemampuan individu terhadap materi yang disampikan (Herawati \& Mursanib, 2019). Setelah mengetahui pemahaman masyarakat terhadap bercocok tanam, kegiatan sosialisasi PKM ini juga bertujuan untuk mengubah pola pikir kelompok mitra tentang bagaimana cara bercocok tanam dengan menggunakan teknik akuaponik dengan memanfaatkan sensor sebagai alat monitoring.

\section{Tolak ukur keberhasilan kegiatan}

Indikator keberhasilan pelaksanaan kegiatan PKM selain dilihat dari pelaksanaan yang sesuai jadwal dan jumlah peserta. Juga bisa dilihat dari minat kelompok mitra akan diskusi atau tanya jawab yang dilakukan. Dari kegiatan tanya jawab tersebut menghasilkan beberapa tambahan informasi berupa media tanam yang dipakai tidak hanya arang melainkan serabut kelapa dan batu kali. Selain itu kelompok mitra menginginkan adanya pelatihan tambahan berupa pembuatan alat monitoring yang disesuaikan dengan kemampuan kelompok mitra.

\section{Tolak ukur keberhasilan dari peserta}
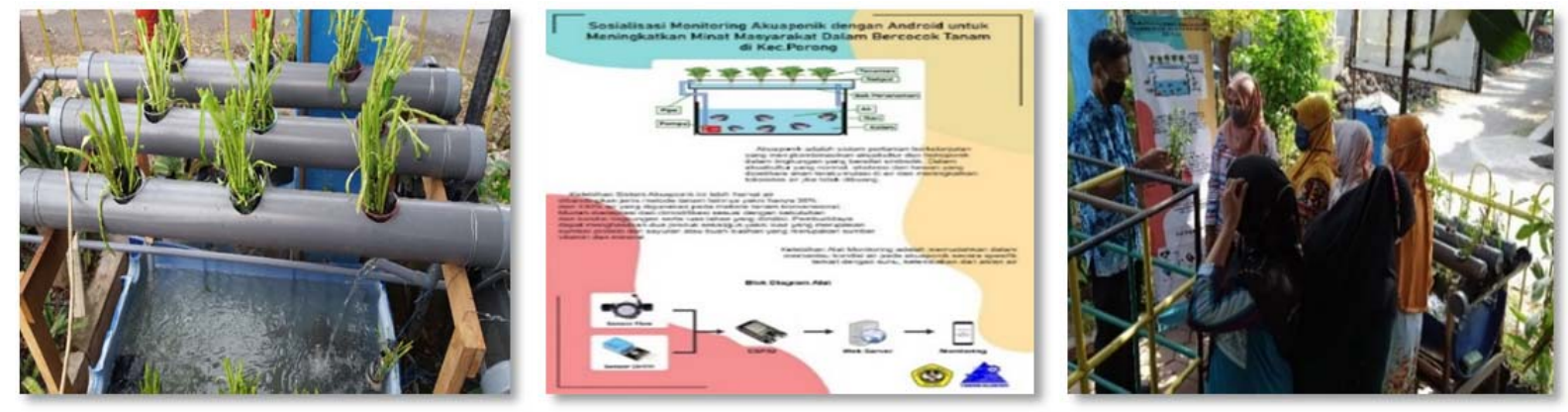

Gambar 3. Percontohan akuaponik di lokasi mitra, brosur akuaponik, dan tanya jawab dengan warga mitra 


\section{Monitoring Akuaponik dengan Android untuk Meningkatkan Minat Masyarakat dalam Bercocok Tanam di Kecamatan Porong}

Wahyu Dirgantara, Rahman Arifuddin, Irfan Mujahidin

Antusias atau minat peserta dapat terlihat dari proses tanya jawab yang dilakukan saat kegiatan sosialisasi berlangsung dan praktek secara individu yang dilakukan pada prototipe akuaponik.

\section{HASIL DAN PEMBAHASAN}

Kegiatan PKM ini dilaksanakan di Dusun Pojok RT.01 RW.03 Desa Lajuk, Kecamatan PorongKabupaten Sidoarjo. Uraian hasil kegiatan PKM yang dilaksanakan di lokasi mitra memiliki beberapa tahapan.

\section{Peninjauan mitra}

Kegiatan peninjauan lokasi mitra dilakukan untuk mendapatkan data terkait lokasi yang akan digunakan sebagai tempat PKM dan persiapan apa saja yang dibutuhkan untuk tahap awal (Saputra et al., 2018). Pada 10 September 2020 telah dilakukan peninjauan lokasi mitra untuk menentukan lokasi pembuatan prototipe akuaponik dengan menggunakan sistem monitoring, namun pada 03 Oktober 2020 lokasi diubah di KB/TK Baitul Ilmi Dusun Pojok RT.01 RW.03 Desa Lajuk. Hal ini dilakukan dengan maksud dan tujuan mengoptimalkan sasaran yang dituju.

Lokasi pembuatan akuaponik berada di dalam lingkungan KB/TK Baitul Ilmi. Lokasi tempat ini dianggap setrategis karena terlihat dari jalan umum serta adanya fasilitas seperti air, listrik dan wifi. Sehingga tujuan dari pembuatan prototipe akuaponik akan lebih optimal karena bisa diakses dan dilihat oleh semua masyarakat.

\section{Koordinasi}

Setelah peninjauan dilakukan serta mendapatkan gambaran tentang loksai mitra (kelebihan dan kekurangnya), dari hasil peninjauan dilakukan diskusi antara tim PKM dengan kepala sekolah KB/TK Baitul Ilmi untuk mendapatkan cara pelaksanaan serta solusinya. Diskusi dilakukan dengan memberikan penjelasan program dan seluruh rangkaian kegiatan yang akan dilakukan, dan jika terjadi permasalah dalam pelaksanaan dapat segera terselesaikan dan kegiatan dapat berjalan dengan lancar. Dalam kegiatan PKM, koordinasi juga dilakukan dengan ketua Rukun Tetangga (RT.01) perihal perijinan pelaksanaan kegiatan PKM di KB/TK Baitul Ilmi.

\section{Percontohan sistem akuaponik dengan monitoring}

Untuk mempermudah pemahaman masyarakat terkait program yang direncanakan maka dibuatlah sebuah akuaponik dengan menggunakan sensor DHT11 dan flow sensor. Perancangan akuaponik dibuat portable sehingga bisa ditempatkan pada lahan yang sempit atau juga bisa disebelah rumah. 
ABDIMAS: Jurnal Pengabdian Masyarakat Universitas Merdeka Malang Volume 6, No. 1, February 2021: 133-141

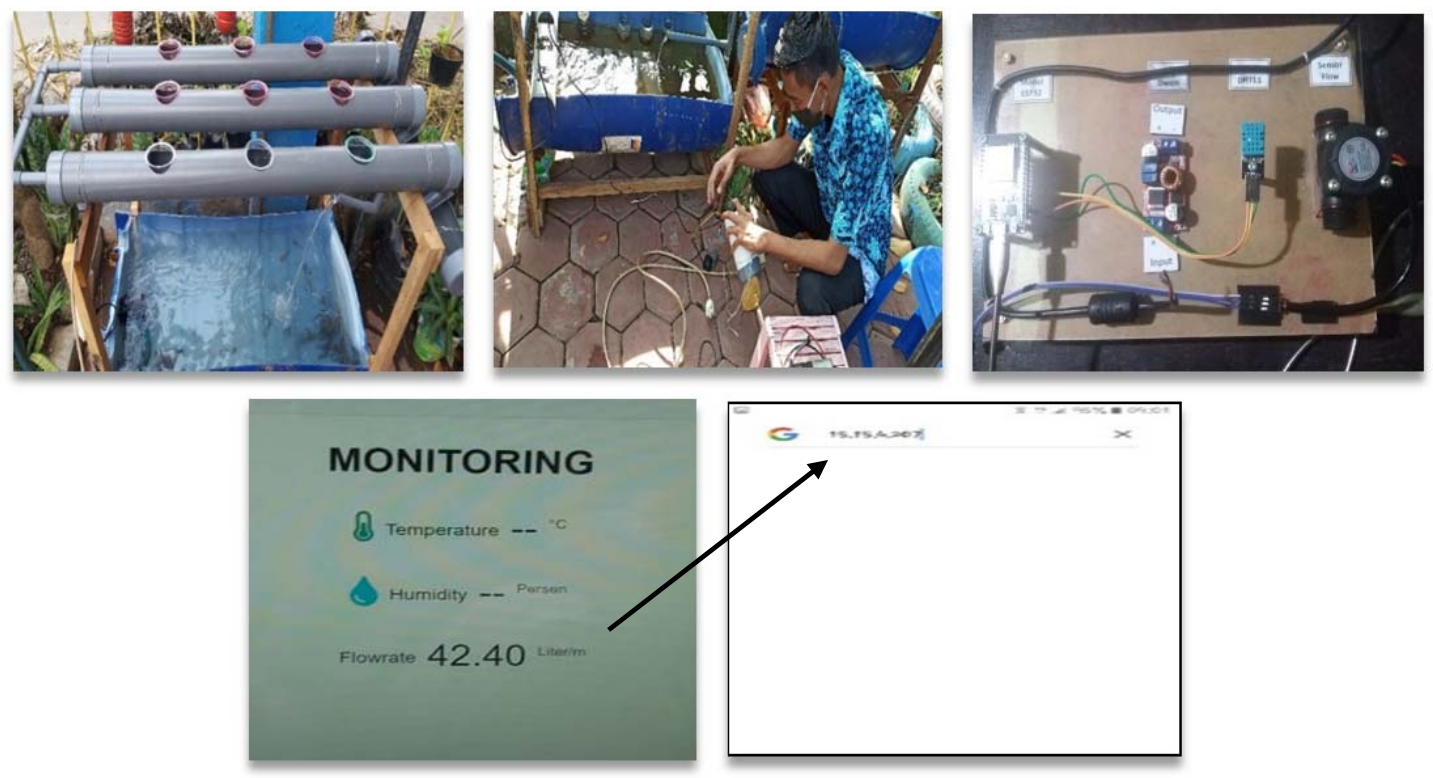

Gambar 4. Desain akuaponik dengan monitoring

Alat dan bahan yang digunakan untuk membuat percontohan akuaponik dengan sistem monitoring antara lain adalah: (1) Drum untuk rumah atau kolam ikan. Pada percontohan, drum dibelah menjadi dua bagian; (2) Pipa dan gelas plastik. Fungsi dari pipa adalah sebagai media tanam dan berfungsi mengalirkan air dari kolam (sirkulasi air). Karena media tanam adalah air maka diperlukan arang sebagai penopang tanaman supaya tidak roboh dan tempat melekatnya akar. Peletakan arang ditempatkan pada gelas plastik yang sudah dilubangi pada bagian bawah sehingga air bisa tetap mengalir secara kontinu; (3) Tanaman berjenis kangkung sebagai filter air kolam yang sudah bercampur dengan kotoran ikan; (4) Kayu untuk kerangkan dari kolam ikan sehingga kolam tidak roboh dan tempat penyangga pipa; (5) Modul ESP32 mikrokontroler yang berfungsi sebagai otak dari alat monitoring, modul ini menyediakan komunikasi Bluetooth dan wifi yang berfungsi sebagai komunikasi data dari alat ke android (handphone); (6) Sensor DHT11 yang berfungsi untuk mendeteksi suhu dan kelembapan udara; (7) Sensor Flowrate yang berfungsi untuk mendeteksi aliran air; (8) Water Pump untuk mengalirkan air dari kolam ikan ke pipa tanaman digunakan water pump (untuk aquarium). Pemilihan water pump yang digunakan berdasarkan jumlah air pada kolam ikan; (9) Wifi untuk mengirimkan data dari ESP32 ke android digunakan wifi. Topologi jaringan yang digunakan adalan Local Area Network (LAN). Wifi yang digunakan dalam PKM ini adalah wifi TK/KB Baitul Ilmi; (10) Tampilan monitoring pada handphone yang menggunakan OS android bisa diakses dengan cara memasukkan ip localhost milik KB/TK Baitul Ilmi pada aplikasi google di handphone android peserta sosialisasi (alamat ip 15.15.4.207). Tampilan pada layar handphone menampilkan temperature dan kelembapan (real time) sedangkan flow sensor / debit aliran air (terbaca setiap 1 menit). Untuk mengetahui ip yang digunakn pada esp32 bisa dilihat pada saat melakukan test running program yang sudah terhubung dengan internet KB/TK Baitul Ilmi. 


\section{Sosialisasi}

Sosialisasi kepada masyarakat merupakan kegiatan inti dalam kegiatan PKM dengan menerapkan protokol COVID-19 yang salah satunya adalah memakai masker. Kegitan ini dilakukan di KB/ TK Baitul Ilmi sebagai Langkah awal untuk mengenalkan kepada masyarakat terkait akuaponik dengan monitoring. Sosialisasi juga dilakukan dengan menyebarkan brosur di masyarakat dan xbanner yang diletakkan pada alat.
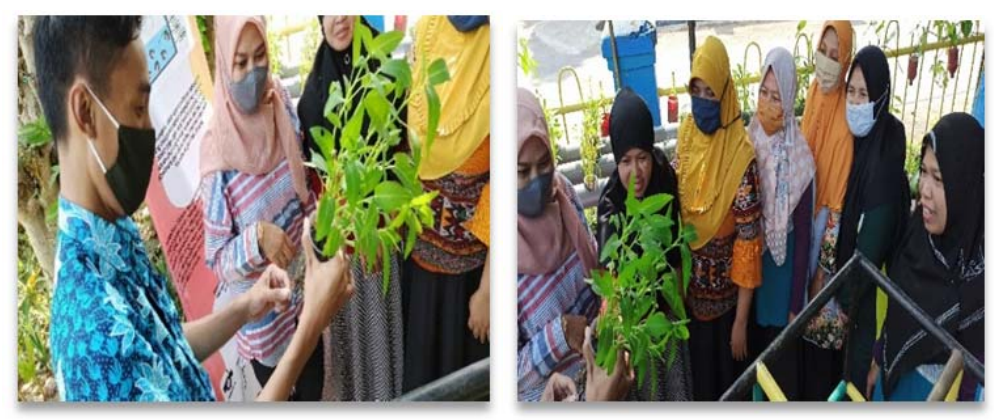

Gambar 5. Sosialisasi akuaponik dengan monitoring ke masyarakat dan antusias ibu-ibu rumah tangga terkait akuaponik

Sesuai dengan tema kegiatan PKM, kegiatan ini berhasil dilakukan dan menghasilkan beberapa potensi luaran yang bisa dioptimalkan. Penjelasan potensi yang dihasilkan dijelaskan pada Tabel 1.

Tabel 1. Potensi yang dikembangkan dari hasil kegiatan PKM

Potensi Pengambangan

Jurnal Ilmiah

Sosial

Pendidikan

\section{Keterangan}

Hasil dari kegiatan PKM yang dilaksanakan dapat dipublikasikan dalam bentuk jurnal atau artikel ilmiah pengabdian kepada masyarakat sehingga dapat memotifasi dalam berocok tanam dan bereksperiimen teknologi untuk pertanian dan perikanan.

- Percontohan akuaponik dengan monitoring membuat kelompok mitra terbuka pola pokirnya dari bercocok tanam tradisonal menjadi modern dengan memanfaatkan teknologi.

- Kegiatan ini juga menghasilkan diskusi baru berupa media tanam yang akan dipakai berupa serabut kelapa dan batu kali.

- Dampak dari sosialisasi PKM ini adalah meningkatnya minat masyarakat akan bercocok tanam dengan teknik akuponik, dan kelompok mitra menginginkan adanya pelatihan pembuatan monitoring yang sederhana yang disesuaikan dengan kemampuan mitra.

Percontohan akuaponik dengan monitoring bisa dijadikan sebagai pembelajaran untuk masyarakat dan anak-anak untuk bercocok tanam menggunakan teknologi. 
ABDIMAS: Jurnal Pengabdian Masyarakat Universitas Merdeka Malang

Volume 6, No. 1, February 2021: 133-141

\section{SIMPULAN DAN SARAN}

\section{Simpulan}

Kegiatan Pengabdian Kepada Masyarakat (PKM) yang dilakukan oleh Dosen Teknik Elekro Universitas Merdeka Malang di Dusun Pojok RT.01 RW.03 Desa Lajuk Kecamatan Porong-Kabupaten Sidoarjo telah berhasil dilakukan. Pelaksanaan mulai dengan pembuatan percontohan akuaponik dan alat untuk monitoring, kemudian dilanjutkan dengan sosialisasi dengan cara pertemuan dengan warga di lokasi akuaponik serta memberikan brosur secara digital ke warga. Dari hasil kegiatan PKM, selain masyarakat belajar teknik bercocok tanam akuaponik, pola pikir masyarakat juga diubah dari bercocok tanam secara manual menjadi menggunakan teknologi tepat guna (menggunakan handphone dan alat monitoring).

\section{Saran}

Kegiatan Pengabdian Kepada Masyarakat terdapat kekurangan sehingga memerlukan saran untuk penyempurnaan kegiatan, antara lain: (1) Pemberian informasi terkait kondisi pertanian di lokasi mitra; (2) Penambahan waktu kegiatan sosialasisasi; (3) Perlu adanya percontohan yang diberikan kepada beberapa warga sehingga peserta bisa mendapatkan hasil langsung dari hasil sosialisasi; dan (4) Untuk sumber energi alat menggunakan sistem energi terbarukan yang ramah lingkungan sehingga pembiayaan listrik tidak dibebankan pada rumah.

\section{DAFTAR PUSTAKA}

Dirgantara, W., \& Arifuddin, R. (2020). Global positioning system berbasis android guna pertempuran kota menggunakan metode fuzzy mamdani. Jurnal Aplikasi Sains, Informasi, Elektronika dan Komputer, 2(1), 90-97.

Herawati, H., \& Mursanib, M. (2019). Meningkatkan kemampuan anak berkomunikasi melalui metode tanya jawab di Kelompok B TK Andine Palupi. Bungamputi, 5(1).

Herdiana, D. (2018). Sosialisasi kebijakan publik: Pengertian dan konsep dasar. Jurnal Ilmiah Wawasan Insan Akademik, 1(3), 13-26.

Hidayat, S. I. (2007). Dampak Lumpur Lapindo Sidoarjo pada sektor pertanian. Jurnal Pertanian MAPETA, 10, 7-12.

Kuswinta, A. J., \& Arimbawa, I. W. A. (2019). Implementasi IoT cerdas berbasis Inference Fuzzy Tsukamoto pada pemantauan kadar $\mathrm{pH}$ dan ketinggian air dalam akuaponik. Journal of Computer Science and Informatics Engineering (J-Cosine), 3(1), 65-74. https://doi.org/10.29303/jcosine.v3i1.245

Prasetya, B., Setiawan, A. B., \& Hidayatulail, B. F. (2019). Fuzzy mamdani pada tanaman tomat hidroponik (Mamdani fuzzy on hydroponics tomato plants). JEEE-U (Journal of Electrical and Electronic Engineering-UMSIDA), 3(2), 228-263. https://doi.org/10.21070/jeee-u.v3i2.2471

Rahayu, N., Utami, W. S., \& Razabi, M. M. (2018). Rancang bangun sistem kontrol dan pemantauan aquaponic berbasis IoT pada Kelurahan Kutajaya. Innovative Creative and Information Technology, 4(2), 192-201. 
Saputra, H., Rudianto, R., Setiawan, D., \& Nugroho, R. A. (2018). Desa wisata hidroponik sebagai ipaya Pemberdayaan masyarakat Desa Sidomulyo Kecamatan Anggana Kabupaten Kutai Kartanegara. Jurnal Pengabdian Kepada Masyarakat, 24(1), 587-593.

https://doi.org/10.24114/jpkm.v24i1.9656

Syofian, A. (2016). Pengendalian Pintu Pagar Geser Menggunakan Aplikasi Smartphone Android dan Mikrokontroler Arduino Melalui Bluetooth. Jurnal Teknik Elektro, 5(1), 45-50.

Wibowo, R. H., Sipriyadi, S., Sugianto, N., Sembiring, S. R., Hutasoit, M., Serlyani, Y. K., \& Hidayah, T. (2020). Aplikasi akuaponik sayur organik-ikan kele dalam ember (asoileledamber) di Kota Bengkulu. Jurnal Pengabdian Pada Masyarakat, 5(3), 656-664. 